\title{
Author: I de Villiers
}

\section{SPATIAL PRACTICES IN LOWLIEBENHOF: THE CASE OF}

MAPHANGO V AENGUS LIFESTYLE PROPERTIES (PTY)

\section{LTD}

\section{ISSN 1727-3781}

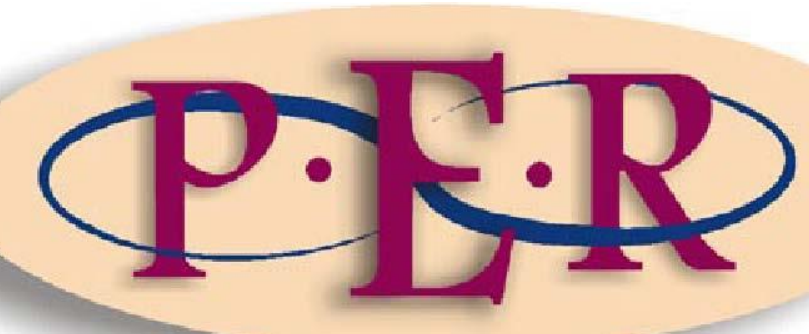

2014 VOLUME 17 No 5 


\section{SPATIAL PRACTICES IN LOWLIEBENHOF: THE CASE OF MAPHANGO V AENGUS LIFESTYLE PROPERTIES (PTY) LTD}

I de Villiers*

\section{Introduction}

\section{The case of Maphango $v$ Aengus Lifestyle Properties (Pty) $L t d^{d}$ raised a number of} interesting questions in its aftermath. Some of these inquiries include an extensive analysis of rent control ${ }^{2}$ and conceptualising an unfair practice regime in landlordtenant law. ${ }^{3}$ The case has also been used for illuminating the complex concept of subsidiarity ${ }_{1}^{4}$ for discussions on a culture of commitment to the common law, ${ }^{5}$ and to illustrate the "two sides of the coin" that is the South African law of lease. ${ }^{6}$ Central to the case is also the tension between inner city rejuvenation projects and the interests of those who have made a home in the not-yet-rejuvenated inner city. ${ }^{7}$ The

Isolde de Villiers. LLB LLM (UP). Lecturer, Department of Jurisprudence, University of Pretoria. Email: Isolde.devilliers@up.ac.za.

Maphango v Aengus Lifestyle Properties (Pty) Ltd 20125 BCLR 449 (CC) (hereafter Maphango).

Sue-Mari Maass relies on Karl Klare's project of transformative constitutionalism (Klare 1998 SAJHR 146) in Maass 2012 SAPL 652-670. In the light of the possibility presented by the project of transformative constitutionalism to challenge unequal power relationships that undermine constitutional values, she welcomes the Constitutional Court's interpretation of the Rental Housing Act 50 of 1999 in Maphango because it enables Tribunals to provide increased tenure protection to tenants that are struggling.

3 Maass 2012 PER 41-100. She refers to Maphango v Aengus Lifestyle Properties 20115 SA 19 (SCA) and two other Supreme Court of Appeal decisions: Occupiers, Shulana Court, 11 Hendon Road, Yeoville, Johannesburg v Steele 20104 All SA 54 (SCA) and City of Johannesburg Metropolitan Municipality v Blue Moonlight Properties 20114 SA 337 (SCA). All three of these cases concerned disputes between low-income tenants and private landlords.

$4 \quad$ See Van der Walt Property and Constitution 57-61.

5 Frank Michelman, during a public lecture at the Constitutional Court in 2012, referred to the decision as one that "may or may not" be an example of "the ways in which the dignity of the common law shows up in South African constitutional adjudications" (Michelman 2012 Harvard Public Law Working Paper). He describes this culture of commitment as an "inclination of lawyers to defer to the common law, including a reluctance of lawyers to conclude that the words of a statute, or of the Constitution, have actually meant to command a deviation from the common law" (Michelman 2012 Harvard Public Law Working Paper 3).

$6 \quad$ Philip Stoop relied on the case to illustrate what he refers to as the two sides of the coin that is the South African law of lease (Stoop 2013 IJPL 329-340). On the one hand, s 26 of the Constitution of the Republic of South Africa, 1996 (hereafter the Constitution) provides that the state must afford access to adequate housing. On the other hand, landlords should be protected, as rental housing forms a large portion of the South African housing market. He expresses the concern that if a landlord's right to dispose of his property as he wishes is continuously eroded by a tenant's right to access to adequate housing, the sustainability of the rental market will be affected.

7 The issue of gentrification and city clean-up operations is a well-known problem in Johannesburg. The most recent manifestation of this is the removal of informal traders from the 
narrow focus of this note is the manner in which the Constitutional Court in the Maphango case interpreted the concept of "practice" in the Rental Housing Act and how this in turn reveals the spatial politics of urban spaces. I rely on Michel De Certeau's ${ }^{9}$ theory on the practice of everyday life and bring it in relation to Henri Lefebvre's ${ }^{10}$ notion of inhabitance. My inquiry is informed by the spatial justice turn. ${ }^{11}$ After setting out the facts and litigation background of the case, I discuss the Constitutional Court's treatment of the concept of "practice" in the Maphango case. Thereafter I briefly look at how unfair labour practices are defined and interpreted in the context of labour law in order to establish the significance of this comparable concept and the role it played in determining the content of unfair practices in the context of the Rental Housing Act. Finally I investigate the idea of "practice" from the vantage point of spatial justice, within theories of everyday life, and in conclusion turn briefly to Doreen Massey's ${ }^{12}$ "place called home".

An understanding of "practice" as tactics within the context of spatial justice presents a different angle from which to look at the conduct of both the landlord and the tenant beyond the question of the requirement of continuation or repetition. The argument of the main judgment in the Maphango case raises a clear link between labour and home, which provides a link between spatial practices and spatial politics. ${ }^{13}$ In the context of spatial justice the practices of everyday life are often described as potentially subversive acts that challenge spatial arrangements. The distinction between house and home corresponds with the differentiation between habitat and inhabitance as raised by Lefebvre. ${ }^{14}$ Everyday spatial practices form part of inhabitance and distinguish inhabited places from mere habitats.

inner city of Johannesburg. See for example Tau The Citizen 9 and SERI's condemnation of the crackdown at SERI 2013 http://www.seri-sa.org/index.php/38-latest-news/202-seri-condemnsthe-crack-down-on-informal-traders-in-inner-city-johannesburg-23-october-2013.

Rental Housing Act 50 of 1999 (hereafter the Rental Housing Act).

De Certeau Practice of Everyday Life; De Certeau, Jameson and Lovitt 1980 Social Text.

Lefebvre Critique of Everyday Life; Lefebvre Critique of Everyday Life III and Lefebvre Production of Space.

11 Spatial justice acknowledges that space is intertwined with normative production. See for example Philippopoulos-Mihalopoulos 2010 Int'I JLC 201-216.

12 Massey Space, Place and Gender.

13 This link draws from the work of Lefebvre and his concept of the production of space, which are based on Marxist theories of production and labour.

14 Section 3.4 below deals with the work of Lefebvre. 


\section{Maphango: facts and litigation background}

Lowliebenhof is a block of apartments in the inner city of Johannesburg. It is a ten story apartment block in Braamfontein and the applicants had different rental agreements in terms of which they lived there. ${ }^{15}$ These lease agreements were initially concluded with various landlords and therefore they contained different termination and escalation clauses. ${ }^{16}$ The first lease agreement dated back to 1994. The respondent-landlord became involved in the management of Lowliebenhof in 2007 through an associated company. ${ }^{17}$ The respondent took transfer of the entire block in 2009, improved the building and wanted to increase the rent while claiming that the upgrading of the apartment block was in line with the "city's initiative at refurbishing and upgrading the Johannesburg inner city". ${ }^{18}$ The respondent attempted this increase by cancelling the existing rental contracts and offering new contracts on increased rental terms. The Maphango case concerned the question of whether the landlord was allowed to cancel the leases and evict the tenants in the event that they refused to accept the revised contracts. Even though the revised rental amounts were based on market-related rentals the revision resulted in a significant increase of the existing rent. For some of the tenants it meant a $100 \%$ increase and for others as much as $150 \% .{ }^{19}$

The litigation history of the applicants living in the block had started prior to the respondent-landlord's acquisition of the apartment block as a whole. The landlord prior to the respondent in the case had issued written notices to vacate in September 2008, upon which the tenants had lodged a complaint at the Gauteng Rental Housing Tribunal. ${ }^{20}$ In October 2008 a mediation meeting had been convened

\section{Maphango para 6.}

16 Maphango paras 6-8.

17 In the Supreme Court of Appeal judgment Maphango $v$ Aengus Lifestyle Properties 20115 SA 19 (SCA) para 4, Judge of Appeal Brand explains that "The respondent purchased the property in 2007, but only became the owner in May 2009 ... It was not a party to the leases ... However, by operation of the common law principle of huur gaat voor koop, the respondent became the successor to all rights and obligations deriving from these lease agreements, when it became owner of the building."

18 Maphango para 11.

19 Maphango para 88.

20 In terms of s 13 of the Rental Housing Act. Gauteng Unfair Practices Regulations (PN 4004 in PG 124 of 4 July 2001) (Gauteng Unfair Practices Regulations). Both the Gauteng Unfair Practices 
and because the parties could not reach an agreement at this meeting the matter set down for arbitration to take place in June $2009 .{ }^{21}$ In the interval between mediation and arbitration the landlord at the time had waited for the three-month moratorium ${ }^{22}$ period to expire and in February 2009 had made an application in the Magistrate's court for the tenants to be evicted. ${ }^{23}$ However, subsequent to this application, formal transfer had taken place, the respondent had become the owner of the block, and the eviction proceedings had been withdrawn in May 2009. This withdrawal had not brought about the end of the eviction proceedings though, because the day after withdrawal the new landlord and respondent in this case had instituted fresh eviction proceedings, this time in the High Court. On 7 May 2010 the High Court had granted an eviction order in favour of the landlord. ${ }^{24}$

In the Constitutional Court the majority-formulated question before the court was whether the termination was capable of constituting an unfair practice and not whether the Rental Housing Act prohibited the landlord from terminating the tenants' leases in order to secure higher rents. Judge Cameron referred to the case of Media Workers Association of South Africa v Press Corporation of South Africa $L t d^{25}$ to argue that the question before the court was not merely a question of fact

Regulations and the Procedural Regulations purport to be issued under s 15 of the Act, which gives the National Minister of Housing (Human Settlements) power to make regulations. The Act provides in $\mathrm{s} 7$ that the Member of the Executive Council (the MEC) of a province responsible for housing matters may by notice in the Gazette establish a tribunal in the province to be known as the Rental Housing Tribunal. The Gauteng Rental Housing Tribunal was established in terms of the PN 4216 in PG 127 of 18 July 2001. Maphango para 13.

21 Maphango para 14.

22 S 13(7) of the Rental Housing Act places a three-month moratorium on evictions, given that the tenant continues to pay rent.

23 In terms of $\mathrm{s} 13(7)$ of the Rental Housing Act a landlord may not evict a tenant who is still paying rent until the Tribunal has made a ruling or a period of three months has elapsed. The three months start from the date of the complaint. This leads one to ask why an arbitration date was set for a time after three months from the date of the complaint. The complaint was lodged on 17 September 2008 and three months from then would have been 17 December 2008. The decision is silent on the events between the mediation proceedings and the date on which the arbitration was set down for. This period is, in my view, a key reason for the case's progressing to the Constitutional Court. It may be asked if this had an influence on the Constitutional Court's decision to refer the matter back to the Rental Housing Tribunal.

24 The case in the High Court has not been reported.

25 Media Workers Association of South Africa v Press Corporation of South Africa Ltd 19924 SA 791 (A) (hereafter Perskor). 
but also a question of law be introduced and determined at the stage of appeal. ${ }^{26}$ Judge Cameron held further that the Rental Housing Act applied to the case and had to be interpreted in the light of the Constitution. After finding that the landlord's termination of the leases constituted an "unfair practice" in terms of the Rental Housing Act, the majority referred the matter back to the Rental Housing Tribunal. Emphasis was placed on two Constitutional Court decisions by the court on the right to access to housing, ${ }^{27}$ and on how the "right of access to adequate housing ripples out to private rights". 28

The minority judgment, per Judge Zondo, argued that the main judgment had not decided the issue before the court, namely the decision of the Supreme Court of Appeal, and not the question of whether or not the landlord's conduct constituted an unfair practice in terms of the Rental Housing Act. ${ }^{29}$ Accordingly the minority judgment held that the applicants' leases had been validly terminated. In a concurring judgement Judge Froneman, with Judge Yacoob, agreed with the majority judgment and the decision that the Rental Housing Act should apply. ${ }^{30}$

26 In Maphango note 98 attached to para 47 Judge Cameron refers to the Perskor-case and quotes from paras 798E-I: "... the definition of an unfair practice entails a determination of the effects or possible effects of certain practices, and of the fairness of such effects". The appellate division held that "a decision of the Court pursuant to [whether the conduct is an unfair labour practice] is not a decision on a question of law in the strict sense of the term. It is the passing of a moral judgment on a combination of findings of fact and opinion".

27 In a footnote Judge Cameron refers to the leading court cases in the issue of considering all relevant circumstances: City of Johannesburg Metropolitan Municipality $v$ Blue Moonlight Properties 39 (Pty) Ltd 20122 BCLR 150 (CC); Occupiers of Skurweplaas 353 JR v PPC Aggregate Quarries (Pty) Ltd 20124 BCLR 382 (CC) and Occupiers of Portion R25 of the Farm Mooiplaats 355 JR v Golden Thread Ltd 20124 BCLR 372 (CC).

28 Maphango para 34. Specific reference was made to the fact that debt recovery is subject to judicial consideration of s 26 before creditors can levy execution on the home of a debtor. In this regard the court relied on the Constitutional Court's decisions in Gundwana v Steko Development 20113 SA 608 (CC) and Jaftha v Schoeman; Van Rooyen v Stolz 20052 SA 140 (CC). Maphango para 33: "And while a private landowner cannot be expected to house unlawful occupiers indefinitely, its right not to be arbitrarily deprived of property must be interpreted in conjunction with the constitutional requirement that every eviction be made by court order after considering all the relevant circumstances."

29 The right not to be arbitrarily deprived of property is contained in s 25(1) of the Constitution and the constitutional requirement to consider all relevant circumstances in every case of eviction in $\mathrm{s}$ 26(3). See also Maphango para 146.

30 Maphango para 158. Judge Froneman wrote the majority judgment in the Schubart Park-case decided by the Constitutional Court shortly after Maphango. Judgment was handed down on 9 October 2012 in favour of the Schubart park residents, who had been evacuated by the Tshwane Metro Council in September 2011 because of an alleged safety risk posed by the dilapidated condition of the high-rise apartments (Schubart Park Residents Association v City of Tshwane Metropolitan Municipality 20131 BCLR 68 (CC) (hereafter Schubart Park)). Schubart Park is also 
Froneman J deemed it necessary to add the following, in response to the arguments of the minority judgment:

It is common cause that section 26 of the Constitution is implicated. Interpretation of what constitutes an "unfair practice" under the Act in light of this is thus inevitably a constitutional issue, a matter of law. Interpretation and application of the law under the Constitution is never a mechanical application of rules; it always involves a value judgment. Our Constitution and law are infused with moral values. The days of denying the value-laden content of law are long gone. ${ }^{31}$

The Court was divided on whether or not judgment in terms of the concept of unfair practice should come into play, even though the parties did not expressly place it before the Constitutional Court. The majority viewed it as a question of law and therefore argued that it should be part of the Court's consideration, while for the minority it was a value judgment that had to be raised by the parties and could therefore not be raised by the Court. The concurring judgement argued that the distinction between questions of law and value judgements is a false dichotomy given the requirements of constitutionalism in South African jurisprudence. I now turn to the concept of practice.

\section{$3 \quad$ Practices}

\subsection{The practice of Aengus Propriety Holdings}

The Supreme Court of Appeal relied on the definition of "practice" in the Concise Oxford English Dictionary 32 and rejected the tenants' contention that the termination of their leases contravened the Rental Housing Act based on the argument, amongst others, that the landlord's conduct was an isolated occasion and could therefore not constitute a practice. ${ }^{33}$ As already noted, the majority in the Constitutional Court

an example of struggling tenants in a city high-rise block subjected to the rejuvenation project of the block's owner. Whereas Lowliebenhof in Maphango is owned by a business enterprise, Schubart Park is the property of the city. Tshwane 2055 envisages the refurbishment of the Schubart Park complex as part of the Western Precinct project. In Schubart Park the tenants triumphed over the City of Tshwane Metropolitan Council and the Council was ordered to meaningfully engage with the residents. Unfortunately the 3000-5000 inhabitants of Schubart Park had, by the time that the judgment was given, already been evicted a year earlier. In his judgment Judge Froneman refers to a number of cases on eviction but does not refer to Maphango.

31 Maphango v Aengus Lifestyle Properties 20115 SA 19 (SCA) para 151.

32 Maphango $v$ Aengus Lifestyle Properties 20115 SA 19 (SCA) para 34.

33 Maphango v Aengus Lifestyle Properties 20115 SA 19 (SCA) para 34. 
argued that the Rental Housing Act does apply and should be considered as a question of law, which any party is free to raise at any time. ${ }^{34}$ The minority differed by supporting the argument of the Appellate Division that the consideration of "unfair practice" constituted a question of value judgment and not a question of law. ${ }^{35}$ Maass $^{36}$ stresses the importance of the manner in which Judge Cameron formulated the question: "whether the termination was capable of constituting an unfair practice". She argues that the fact that the Court did not ask if the ground for termination amounted to an unfair practice is an indication that the ground for termination is not markedly significant in determining whether termination of the lease amounted to an unfair practice or not. ${ }^{37}$

In giving content to the concept of "practice" Judge Cameron refers to the Labour Relations Act 28 of 1956 and the 1986 case of Marievale Consolidated Mines v President of the Industrial Court ${ }^{38}$ to highlight that practice as a single act has long been established in South African law. ${ }^{39}$ For him the authority in the Marievale case forms "the interpretive backdrop for understanding the use of the word 'practice' in the Act". ${ }^{40}$ He quotes Judge Goldstone: "a practice does not in any way relate to habitual or repetitious conduct". ${ }^{41}$ Furthermore, he also relies on the definition in the Shorter English Dictionary to argue that one of the ordinary meanings of the word "practice" accords with the meaning of a single act. ${ }^{42}$ The Rental Housing Act lists examples of unfair practices. The nature of these examples is not such that it is

34 Maphango paras 29, 56.

Maphango para 106.

Maass 2012 SAPL 660.

Maass 2012 SAPL note 52.

Marievale Consolidated Mines v President of the Industrial Court 19862 SA 485 (T) (hereafter Marievale).

39 Maphango v Aengus Lifestyle Properties 20115 SA 19 (SCA) para 57. In this regard he refers to Marievale 491H-I, 498B-D. The Marievale interpretation of practice has been applied in Media Workers Association of South Africa v Press Corporation of South Africa Ltd 19924 SA 791 (A) 798G; National Union of Metalworkers of South Africa v Macsteel (Pty) Ltd 19923 SA 809 (A) 814C-D; and National Union of Mineworkers v East Rand Gold and Uranium Co Ltd 19921 SA 700 (A) 734G. See note 111 attached to para 57 of Maphango.

$40 \quad$ Maphango v Aengus Lifestyle Properties 20115 SA 19 (SCA) para 57.

41 Marievale paras 491H-I, 498B-D. See Maphango v Aengus Lifestyle Properties 20115 SA 19 (SCA) note 110 attached to para 57.

42 The Shorter Oxford Dictionary (quoted by Brassey et al New Labour Law 49) defines "practice" as (also) "the action of doing something... an action, a deed". 
necessarily repetitive or continuous. ${ }^{43}$ In the context of labour law, the term "labour practice" can be interpreted to mean a single act. ${ }^{44}$ The majority in Maphango found it problematic that the Supreme Court of Appeal required unfair conduct to be perpetual in order to qualify as a practice and accordingly be challenged under the Rental Housing Act. Judge Cameron finally argues that a limited interpretation of the term "practice" would stifle the Act's aim to give effect to the right of access to adequate housing and would therefore not accord with the Constitution. ${ }^{45}$

\subsection{Unfair labour practices}

Judge Zondo, in the minority judgment, invokes the Labour Relations $A c t^{46}$ in the context of the failed mediation proceedings between the parties on 22 October 2008. The mediator issued a certificate to the effect that the matter had not been resolved. In connection with this certificate Judge Zondo remarks that "[i]t would seem that drafters of the [Rental Housing Act] modelled... [it] along the same lines as the Labour Relations Act 66 of 1995". 47 He refers specifically to measures for dispute resolution in these two acts and lists the similarities: the Rental Housing Act contains a definition of "unfair practice" similar to that in the Labour Relations Act, complaints based on unfair practices in terms of both acts follow the process of conciliation or mediation and, if this fails, to arbitration, the Labour Relations Act establishes the Commission for Conciliation Mediation and Arbitration (CCMA) as a tribunal for conducting most of the mediation and arbitrations, and the Rental Housing Act establishes the Rental Housing Tribunal for this purpose. ${ }^{48}$

43 These examples are stipulated in s 15(1) under the ministerial power to regulate unfair practices, which may amongst other things relate to: (i) the changing of locks; (ii) deposits; (iii) damage to property; (iv) demolitions and conversions; (vi) forced entry and obstruction of entry; (vii) House Rules, subject to the Sectional Titles Act 95 of 1986; (viii) intimidation; (ix) issuing of receipts; (x) tenants' committees; (xi) municipal services; (xii) nuisances; (xiii) overcrowding and health matters; (xiv) tenant activities; (xv) maintenance; (xvi) reconstruction or refurbishment work. Van Niekerk etal Work@Law 169.

45 Maphango v Aengus Lifestyle Properties 20115 SA 19 (SCA) para 57: "The Act is a postconstitutional enactment adopted expressly to give effect to the right of access to adequate housing."

46 Labour Relations Act 66 of 1995 (hereafter the Labour Relations Act).

47 Maphango note 7 attached to para 82.

48 Maphango note 7 attached to para 82. 
The definition of "unfair practice" in the Rental Housing Act was replaced by section 1 of the 2007 Rental Housing Amendment Act. ${ }^{49}$ Prior to this amendment, an unfair practice meant "a practice prescribed as a practice unreasonably prejudicing the rights or interests of a tenant or a landlord". ${ }^{50}$ The definition was explicitly altered to include any act or omission (in the singular) that contravenes the act by either party to a rental agreement. In the light of this extended and seemingly clear definition, the Constitutional Court's extensive reliance on the Labour Relations Act for the interpretation of "practice" in the Rental Housing Act is interesting. The court in Maphango explains that there is a presumption that the legislature is aware of existing judicial interpretations of comparable concepts in legislation. ${ }^{51}$ The 1995 Labour Relations Act and the 1999 Rental Housing Act do not only contain comparable concepts, but excerpts from their long titles, stated purpose and preambles also illustrate their similar objectives. ${ }^{52}$ The Rental Housing Act emphasises the need for mechanisms through which conflicts between tenants and landlords can be resolved speedily at minimum cost to the parties. ${ }^{53}$ In a similar vein the Labour Relations Act reiterates the need for the creation of simple procedures for the resolution of labour disputes through statutory conciliation, mediation and arbitration. Whereas the Labour Relations Act was drafted to give effect to section 27 of the Constitution, the Rental Housing Act was drafted to give effect to section

Rental Housing Amendment Act 43 of 2007.

The Amendment Act therefore added the current paragraph (a) to the current paragraph (b) of the definition.

Maphango v Aengus Lifestyle Properties 20115 SA 19 (SCA) para 57. In footnote 112 Judge Cameron refers to the following cases in support of this presumption: Fundstrust (Pty) Ltd (in liquidation) v Van Deventer 19971 SA 710 (A) 732A-B; S v Marais 19823 SA 988 (A) 1017E-G, per Acting Judge of Appeal Botha, concurring in the majority judgment; Cooper $v$ Trustee in Insolvent Estate of Pretorius 19673 SA 602 (0) 610-611. The following authors are also referenced for authority on this point: De Ville Constitutional and Statutory Interpretation 216217; Devenish Interpretation of Statutes 135; and Du Plessis Interpretation of Statutes 70.

By invoking the preamble of the Rental Housing Act, the Constitutional Court in Maphango emphasises that "rental housing is a key component of the housing sector" and that there is a "need to promote the provisions of rental housing" (Maphango para 35).

Part A of Schedule 4 to the Constitution provides that housing is a functional area of concurrent national and provincial competence. The Rental Housing Act made provision for provincial measures to secure its practical operation. From the preamble of the Rental Housing Act: "a need to balance the rights of tenants and landlords and to create mechanisms to protect both tenants and landlords against unfair practices and exploitation"; definition of "unfair practice" ("a practice prescribed as a practice unreasonably prejudicing the rights or interests of a tenant or a landlord") and s 13(5) (rent determinations must be "just and equitable to both tenant and landlord"). 
26 of the Constitution. ${ }^{54}$ Drafted in close proximity as constitutional legislation, these acts have a shared political and legal culture within which they came into existence. The minority, despite not being prepared to entertain the question of "unfair practice" as a question of law in the case, nonetheless concedes to the similarities between the Labour Relations Act and the Rental Housing Act.

The difference between proving an unfair labour practice in terms of the Labour Relations Act as opposed to discrimination as defined in the Constitution and the Employment Equity $A c t^{55}$ is important for establishing the correct forum for resolving the dispute. ${ }^{56}$ Unless the parties agree to arbitration, disputes involving discrimination must be referred to the Labour Court or the civil courts for adjudication. Unfair labour practice disputes, in terms of section 186(2), must be referred for arbitration under the Labour Relations $A c t .{ }^{57} \mathrm{~A}$ comparable restriction appears in the Rental Housing Act. Housing Tribunals can hear matters concerning unfair practices, but not matters dealing with evictions. ${ }^{58}$ The Rental Housing Amendment Act 43 of 2007 expressly deleted subparagraph (v), namely evictions, from the list of unfair practices in the ministerial regulatory powers. ${ }^{59}$

54 The question of unfair labour practices intersected with unfair rental practices in the case of SAFRAWU obo Members / Rainbow Farms 200211 BALR 1184 (CCMA). In this case the respondent rented out houses to some of the applicant's members, who were farm workers of the respondent. After not increasing the rent of these houses the respondent proposed to raise the rental of houses which it leased to some of the applicant's members. The applicant claimed that this constituted an unfair labour practice in relation to the provision of benefits. The respondent denied that the rented houses constituted a benefit. The commissioner held that it was unnecessary to determine if the provision of housing was a "benefit" as contemplated in the definition of unfair labour practice, because the union had failed to prove that the company had acted unfairly by proposing to increase the rentals. The company had notified the applicant of its intention to do so, and the matter had been discussed and negotiated. The case was brought and considered in terms of the Labour Relations Act and the Commission found that the provision of houses to employees did not constitute a benefit and that the increase therefore did not constitute an unfair labour practice. Had the dispute been brought in terms of the Rental Housing Act, the increase would have fulfilled the definition of unfair practice in terms of the Rental Housing Act. Employment Equity Act 55 of 1998.

Grogan Workplace Law 74.

Grogan Workplace Law 74.

S 13(4) of the Rental Housing Act.

59 The subparagraph was deleted by s 7(b) of the Rental Housing Amendment Act 43 of 2007. See also Maass 2012 SAPL 660 for a discussion of other amendments trough the Rental Housing Amendment Act. 
The definitions for "unfair labour practice" in the Labour Relations Act and "unfair practice" in the Rental Housing Act read respectively:

Unfair labour practice means any unfair act or omission that arises between an employer and an employee involving-

(a) unfair conduct by the employer relating to the promotion, demotion, probation (excluding disputes about dismissals for a reason relating to probation) or training of an employee or relating to the provision of benefits to an employee;

(b) the unfair suspension of an employee or any other unfair disciplinary action short of dismissal in respect of an employee;

(c) a failure or refusal by an employer to reinstate or re-employ a former employee in terms of any agreement; and

(d) an occupational detriment, other than dismissal, in contravention of the Protected Disclosures Act, 2000 (Act No. 26 of 2000), on account of the employee having made a protected disclosure defined in that Act. ${ }^{60}$

unfair practice means-

(a) any act or omission by a landlord or tenant in contravention of this Act; or

(b) a practice prescribed as a practice unreasonably prejudicing the rights or interests of a tenant or a landlord. ${ }^{61}$

The Labour Court ruled that for employees to succeed with actions based on unfair labour practices the conduct must fall within this definition. ${ }^{62}$ The definition of "(unfair) practice" in the Labour Relations Act seems to refer mostly to conduct that consists of single acts, and does not necessarily need to be continuing conduct. The continuing nature of unfair labour practices does become relevant, however, in determining when disputes should be referred to a bargaining council or the CCMA for conciliation. In terms of section 191(1) of the Labour Relations Act the unfair

60 This definition can be found in s 186(2) of the Labour Relations Act. S 23(1) of the Constitution also guarantees a fundamental right to fair labour practices by stating: "Everyone has the right to fair labour practices." This fundamental right entails three components, namely: (a) persons entitled to the right. It is clear that every person involved in an employment relationship, whether an employee, employer or body or entity, is entitled to fair labour practices; (b) a labour practice; and (c) a labour practice which is fair. It is uncertain, however, what meaning should be attached to the expression "fair labour practices" as referred to in the Constitution. In the Labour Relations Act the concept of unfair labour practice has been removed from Schedule 7 and incorporated within the Labour Relations Act alongside the dismissal provisions. The scope thereof remains basically the same but changes lie in the need to refer these forms of dispute within 90 days of occurrence or knowledge.

61 See the definition section of the Rental Housing Act.

62 Nawa v Department of Trade and Industry 19987 BLLR 701 (LC). 
labour practice dispute should be referred within 90 days from the commission of the unfair labour practice or from the date when the employee became aware of the unfair labour practice. The Labour Appeal Court considered the requirement of unfair labour practices as continuing in the case of $S A B C L t d v C C M A .{ }^{63}$ In this case the court acknowledged that unfair labour practices could have "on-going" effects, but the court also accepted that some unfair labour practices may indeed consist of "once-off" actions. ${ }^{64}$ The question in the case concerned the time frame within which disputes based on unfair labour practices should be referred. The court found that a dispute can be referred at any time, as long as the effects of the unfair labour practice are still continuing. In this case the employer paid similarly qualified and skilled employees different salaries for doing similar work. According to the Labour Appeal Court the alleged discrimination was continuing and repetitive and "end[ed] only when the employer cease[d] paying different salaries". ${ }^{65}$ Even though it was important in this case to acknowledge the on-going nature of the effects of unfair labour practices, the practices themselves were not continuous. From the definition and the cases discussed it is clear that continuation is not a requirement for acts to constitute "(unfair labour) practices" in terms of the Labour Relations Act.

Apart from the question of the singular or continuous nature of practices, the Maphango decision also shows the way in which spatial practices constitute and are constituted by social and power relationships. It is not only the landlord that exercises practices (be they constant or once-off) in the space of the apartment block, but also the tenants. Before I consider the practices of the landlord and tenants, I look at the issue of the practices of employees in the context of labour law.

63 SABC Ltd v CCMA 20103 BLLR 251 (LAC). The decision dealt mainly with an application for condonation and the date of the alleged unfair practice was therefore of the essence. It concerned the promotion or upgrading of employees to a higher post level. The aggrieved employees were doing similar work and had the same or similar skills as three other employees who were promoted while the aggrieved respondents in the case were not promoted. The employees were denied promotion in 1998 and the dispute was referred only in 2005. The court found that the date of the dispute did not coincide with the date on which the respondent employees were denied promotion and that the CCMA's designation of the referral date as "ongoing" was correct. See also Grogan Workplace Law 75.

$64 S A B C$ Ltd v CCMA 20103 BLLR 251 (LAC) para 27. 
Employees can allege unfair practices committed by the employer, but the converse is not possible, in terms of the decision of the Labour Appeal Court in National Entitled Workers Union (NEWU) v CCMA. ${ }^{66}$ The decision of the Labour Court was confirmed by the Labour Appeal Court, namely that an employee's conduct cannot constitute an unfair labour practice under the Labour Relations Act or the Constitution, and added that legislation that enabled employers to institute actions based on the unfair practices of their employees would diminish the power of employees and "would be a step backwards in the field of labour relations and employment law in our country". ${ }^{67}$ The limitation on the remedy for unfair labour practices available to employers pertains to the consideration of the fairness of practices. Employees do engage in once-off and on-going practices in the space of the workplace, just like tenants in rented spaces. In the following section I consider the practices of both landlord and tenant, what De Certeau would refer to as "practitioners of urban space". ${ }^{68}$ The question of what constitutes urban spatial practices could also be asked for purposes other than that of instituting actions based on unfair practices in terms of the Rental Housing or other Act. It can also be raised in order to ask how certain spatial practices can be linked to the way in which a landlord and a tenant perceive of their space, how the law endorses and enforces this engagement, and how space produces and is produced by certain relationships of power. In order to address this, I turn to theory on the practices of everyday life.

66 National Entitled Workers Union v Commission for Conciliation, Mediation and Arbitration 20077 BLLR 623 (LAC). See also Reddy v KwaZulu-Natal Department of Education and Culture 200324 IL] 1358 (LAC) for the requirement that the alleged act should be between an employer and an employee. The trade union NEWU referred a dispute to the CCMA, alleging that one of their union officials had committed an unfair labour practice by resigning, not serving the required three month notice period, and commencing employment with another trade union on the day he resigned. According to the CCMA the case was closed due to a lack of jurisdiction as the conduct did not constitute an unfair labour practice. On review the Labour Court ruled that the concept of an unfair labour practice contemplated by Item 2 of Schedule 7 to the Labour Relations Act "does not embrace a labour practice committed by an employee vis-a-vis an employer" and that the CCMA correctly dismissed the dispute.

$67 \quad$ National Entitled Workers Union v Commission for Conciliation, Mediation and Arbitration 20077 BLLR 623 (LAC) para 22.

68 De Certeau Practice of Everyday Life iv. 


\subsection{The practice of everyday life: making do, strategies and tactics}

Judge Cameron chooses the word "live" as opposed to "reside" or "stay" to describe the tenants' relationship with Lowliebenhof: "The flats are their homes and they live there". ${ }^{69}$ The use of the word "live" interlaces the fact of their living with these apartments and with their homes. A February 2010 satellite photo shows an Aengus Lifestyle Properties poster at the entrance of Lowliebenhof displaying the words: "Do you want the ultimate living space?"10 This creation of "ultimate living spaces" at the cost of living and "making do" in the city space stands central to this case. The terms "live" (verb, inhabit) and "living space" (habitat) capture the core of the Maphango case: life had to make way for ultimate living spaces and homes had to be turned into profitable units. These opposing views of the space of Lowliebenhof relate closely to a difference in spatial practices.

In considering what an interpretation of "practice" in the context of spatial justice might entail, I rely on the work of De Certeau. ${ }^{71}$ In his two-volume book The Practice of Everyday Life he approaches the idea of a "practice" in a different way from that of the courts in Maphango. ${ }^{72}$ According to De Certeau ${ }^{73}$ a "practice" can be classified as a "strategy" or as a "tactic". I suggest that the same distinction applies to the practices of landlords and tenants. Place stands central to the distinction. Strategies assume a specific circumscribed place, but tactics are independent of "proper" places. ${ }^{74}$ Where strategy asserts power, tactics carry the potential to subvert it. De Certeau ${ }^{75}$ considers the value of everyday practices as tactics that are available to ordinary people to reclaim their own autonomy from the pervasive power of culture, politics and commerce. The connection between force or power and practices is clear from the outset. In this sense De Certeau exposes the

69 Maphango v Aengus Lifestyle Properties 20115 SA 19 (SCA) para 2.

70 Google Maps $2010 \mathrm{https}: / /$ maps.google.co.za/maps?ie=UTF-8\&q=Lowliebenhof\&fb=1\&gl=za\& hq=lowliebenhof\&hnear=0x1e95619cbec65033:0xf66262b07a847b4c,Pretoria\&cid=0,0,6666383 01094739748\&ei=8HWDUpmFdCihgewj4GwDw\&ved=0CJgBEPwSMAs.

71 De Certeau Practice of Everyday Life; De Certeau, Jameson and Lovitt 1980 Social Text.

72 De Certeau Practice of Everyday Life; De Certeau, Giard and Mayol Practice of Everyday Life Volume 2.

73 De Certeau, Jameson and Lovitt 1980 Social Text 5.

74 De Certeau Practice of Everyday Life xix.

75 He dedicates the essay to the "ordinary man. The common hero" (De Certeau, Jameson and Lovitt 1980 Social Text 3). 
seemingly ordinary as something powerful. Power and place are central to De Certeau's conceptualisation of practice. ${ }^{76}$ Exercises of power are not necessarily acts performed continuously by an individual and a practice can be exercised by a larger community. An individual's participation in these actions, albeit only once, then becomes a practice by virtue of its association with that of the broader group, and by extension is then an expression (or subversion) of power. ${ }^{77}$ De Certeau's understanding of everyday practices has been criticised from a Marxist perspective for being a "prevailing 'redemptive' model of the productive consumer". ${ }^{78}$ Chris Butler, ${ }^{79}$ with reference to the work of John Roberts, explains that De Certeau's model bypasses the importance of the everyday for a "critique of culture" and for "the development of radical forms of politics". My focus is therefore not on De Certeau's emphasis on consumption, but rather on his distinction between strategies and tactics and how these practices confirm or subvert power. I relate this distinction to habitat and inhabitance as understood by Lefebvre.

De Certeau's concept of practice is described in terms of art and closely associated with creativity: the "art of using" or "making" or "making do". 80 To explain the formal structure of practices he considers on the one hand certain ways of "making" according to their value for strategy: "functions that make possible (or permit) everyday practices". ${ }^{81}$ On the other hand he looks at poetic ways of "making do" for their tactical value: from "familial practices" to "the tactics of the art of cooking". ${ }^{82}$ De Certeau also makes a case for the city walker as a voyeur. ${ }^{83}$ Walking in the city has its own logic or "rhetoric". ${ }^{44}$ The ordinary walkers live on the streets of the city where visibility begins, they live down below as opposed to those who possess a

\footnotetext{
De Certeau Practice of Everyday Life xv. De Certeau Practice of Everyday Life xiv. Butler Henri Lefebvre 8.

Butler Henri Lefebvre 107. Butler relies on Roberts Philosophizing the Everyday 2-4.

De Certeau Practice of Everyday Life xv.

De Certeau Practice of Everyday Life xiv.

De Certeau Practice of Everyday Life xv.

Under spatial practices he dedicates chapters to "Walking in the City" (91-110), "Railway Navigation and Incarceration" (111-114) and "Spatial Stories" (115-130).

84 De Certeau Practice of Everyday Life 92.
} 
privileged, panoramic view of the city. ${ }^{85}$ For him the inhabitants of the city write the urban text and fill the empty space with the life they breathe into it. ${ }^{86}$

In contrast to strategies, tactics, according to De Certeau, ${ }^{87}$ are calculated actions determined by "the absence of a proper place". Strategies seek to establish their own place and are connected to power. They keep the existing power in place and assert power. ${ }^{88} \mathrm{He}$ calls strategy the "calculus (or the manipulation)" of power relationships, which become possible whenever a subject of will and power can be isolated. This form of making constitutes the manipulation of force made possible by the power of a subject. ${ }^{89}$ Strategic rationalisation, in management, begins by distinguishing its "appropriate" place from an "environment", that is, the "place of its own power and will"..$^{90}$

Tactics on the other hand are determined by the absence of power, ${ }^{91}$ and take advantage of opportunities. ${ }^{92}$ Within the framework of De Certeau many everyday practices are tactical: talking, moving about, reading and cooking. A tactic operates "blow by blow, ... profits from and depends upon 'occasions' ... It poaches there. It creates surprise." ${ }^{13}$ The Maphango case considered the conduct of Aengus Propriety Holdings as a practice. The "practice" of renovating dilapidated inner-city blocks and then charging higher rentals is a well-known strategy of business-driven landlords. De Certeau ${ }^{94}$ describes oppositional practices or tactics as an art of the weak: "The weaker the forces which are subjected to strategic direction, the more they will be vulnerable to wile".

\footnotetext{
85 De Certeau Practice of Everyday Life 94.

86 De Certeau Practice of Everyday Life 96.

87 De Certeau, Jameson and Lovitt 1980 Social Text 6.

88 De Certeau Practice of Everyday Life xx.

89 De Certeau lists businesses, armies, cities and scientific institutions as examples of subjects whose power and will enables strategies (De Certeau Practice of Everyday Life 36).

90 De Certeau, Jameson and Lovitt 1980 Social Text 5.

91 De Certeau Practice of Everyday Life 38.

92 De Certeau Practice of Everyday Life 36.

93 De Certeau, Jameson and Lovitt 1980 Social Text 6: "Power is bound by its very visibility. In contrast, trickery is possible for the weak ... The weaker the forces at the disposition of the strategist, the more the strategy ... is transformed into tactics."

94 De Certeau quotes Von Clausewitz De la Guerre 212-213. De Certeau, Jameson and Lovitt 1980 Social Text 6.
} 
De Certeau continues by suggesting various ways in which tactical practices of consumers can be considered afresh. He considers activities such as walking, dwelling, reading and cooking as activities that present "characteristics of tactical ruses and surprises: tricks of the 'weak' within the order established by the 'strong'". ${ }^{95}$ This approach to practice as tactics links with the idea of inhabitance and therefore with the notion of home. Translating the words of Judge Cameron in terms of this description, his statement could read: "The flats are their homes" and they inhabit them, they perform tactical practices of everyday life there. The unfair practice of the landlord belongs to the realm of strategy, which is confined to space and reliant on power. The everyday practices of the tenants, in their insistence on continuing to inhabit the apartments after eviction notices had been served ${ }^{96}$ can be described in De Certeau's terms as tactics: not confined to space and aimed at disrupting the power of private property.

De Certeau brings his own work in relation to that of Foucault and Bourdieu. ${ }^{97}$ Both of these theorists viewed practices as a way in which to explain society in relationship to structures. ${ }^{98}$ Foucault's interest in practices concerned the conditions produced by the practices and Bourdieu on the other hand was interested in the conditions that produced the practices. ${ }^{99}$ De Certeau relates strategies to the Foucauldian synonyms for educational, penitential and medical processes: "instrumentalities", "techniques", or "mechanisms". ${ }^{100}$ Procedures that do not have "their own place on which the panoptic machinery can operate" are the ordinary practices or tactics of De Certeau. ${ }^{101}$ Bourdieu's concept of habitus or technicity also informed De Certeau's work on practice. ${ }^{102}$ Engaging in a strategy in the Bourdieuian

95 De Certeau, Jameson and Lovitt 1980 Social Text 8.

96 The first applicant, who has given her name to the case, Ntombidzodwa Yvonne Maphango, got married in the time that the application was first brought and its hearing in the Consitutional Court. In the citation of the parties, the words (now Mgidlana) appear next to her name. Life went on and she continued to perform the practices of everyday life in spite of the court case.

97 De Certeau thoroughly discusses this in the chapter entitled "Foucault and Bordieu" (De Certeau Practice of Everyday Life 45-60).

98 De Certeau Practice of Everyday Life 57.

99 De Certeau Practice of Everyday Life 58.

100 De Certeau Practice of Everyday Life 45. He refers in particular to Foucault Surveiller et Punir. De Certeau further also relies on Bourdieu Le Métier de sociologue.

101 De Certeau Practice of Everyday Life 49.

102 De Certeau Practice of Everyday Life 51. 
sense is similar to participating in a trick in a card game: it depends both on the hand that has been dealt and the skill or ability to play cards. ${ }^{103}$ Habitus refers to the expectations and outlooks of certain social groups, that are acquired through participation in everyday life. For the purposes of the Maphango decision, the link that Bourdieu introduces between habitus and habitat is of importance. All of the practices described as habitus (strategies) are dominated by what De Certeau calls "an economy of proper place". ${ }^{104}$ A politics of place therefore forms the base of all these strategies. ${ }^{105}$ Tactics, on the other hand, do not have a "proper" place and therefore should depend on time and use the institutional and symbolic organisation in such an independent and self-governing way that they usurp scientific representations of society. ${ }^{106}$ De Certeau understands home to incorporate both the house (property) and the family (the genealogical body). He links this dual understanding with practices and the way in which practices reproduce two complementary forms of "'dwelling': wealth and the body". ${ }^{107}$ The dwelling provides the habitus with its form, but it does not give content. Dwelling is therefore "hidden in the theory under the metaphor of the habitus". ${ }^{108}$ In the light of the critique that De Certeau redeems consumption through his understanding of everyday practices, I link his distinction between strategies and practices to Lefebvre's differentiation between habitat and inhabitance. In the context of the Maphango decision this distinction can be translated into the difference between "we create the ultimate living spaces" ${ }^{109}$ and "these are [our] homes and [we] live here". ${ }^{110}$

\footnotetext{
103 De Certeau Practice of Everyday Life 53-54.

104 De Certeau Practice of Everyday Life xix, 55.

105 For De Certeau, Bourdieu's theory "throws a blanket" over tactics "as if to put out their fire" (De Certeau Practice of Everyday Life 59).

106 De Certeau Practice of Everyday Life 59.

107 De Certeau Practice of Everyday Life 215 note 24.

108 De Certeau Practice of Everyday Life 60.

109 The slogan of Aengus Lifestyle Properties.

110 The words Judge Cameron uses to describe the tenants at Lowliebenhof.
} 


\subsection{Spatial practices and inhabitance ${ }^{111}$}

Depictions of the everyday in the work of Lefebvre draw deeply on the notion of inhabitance, which he relies on to explain the human body's relationship to space and to express the political dimensions of the urban landscape. ${ }^{112}$ In the period after World War II Lefebvre wrote the Critique of Everyday Life in an attempt to address alienation in everyday life through the theories of Marxism. ${ }^{113}$ For Lefebvre, his introduction of the notion of the "everyday", which enabled an account of alienation beyond economic forms of domination, was his most significant contribution to Marxist thought. ${ }^{114}$ The post-war period was marked by a shift from inhabitance to habitat. For Lefebvre inhabitance is embodied, whereas habitat is functionalist and instrumentalist. ${ }^{115}$

In conversations before the adoption of the Constitution and the inclusion of section 26 , Geoff Budlender ${ }^{116}$ suggested that it may be "more appropriate to talk of the right to shelter and a home, than the right to housing". For him the phrase "right to housing" conjured up images of "long queues of people waiting at a government office to be allocated a matchbox house". ${ }^{117}$ He argued that people need the state to provide land and access to clean water with "an administration which encourages rather than obstructs" attempts to build your own house. ${ }^{118}$ I will extend this call to a call for inhabitance and an interpretation of the right to housing that acknowledges inhabitance as opposed to habitat.

Lefebvre highlights the rationality in the practices of urban planners and city administrators and argues that this leads to a "bureaucratic society of controlled

111 See also Van Marle and De Villiers 2013 AFL 129-145 for a discussion of inhabitance in the context of Schubart Park in the city of Tshwane/Pretoria. I should like to thank Karin van Marle for valuable insights and for shaping my understanding of Lefebvre in the process of coauthoring and over many discussions and conversations.

112 Butler Henri Lefebvre 116.

113 Lefebvre Critique of Everyday Life.

114 Butler Henri Lefebvre 5.

115 Butler Henri Lefebvre 7.

116 The Department of Private Law of the University of South Africa hosted a seminar on 2 November 1990 and the papers read were taken up in an edited collection (Van der Walt Land Reform). Budlender "Towards a Right to Housing" 50.

117 Budlender "Towards a Right to Housing" 50.

118 Budlender "Towards a Right to Housing" 50. 
consumption". ${ }^{119}$ This society is marked by the everyday as structured by the aesthetic and political dominance of technological modernism. ${ }^{120}$ Modernism as a technological practice (technicity or Bordieuian habitus) and devoid of ideology (politics) contributed to the demise of inhabitance and the rise of habitat. ${ }^{121}$

The user's space is lived - not represented (or conceived). When compared with the abstract space of the experts (architects, urbanists, planners), the space of the everyday activities of users is a concrete one, which is to say, subjective. As a space of 'subjects' rather than of calculations, as a representational space, it has an origin, and that origin is childhood, with its hardships, its achievements, and its lacks. ${ }^{122}$

Within the spatial practices of tenants and landlords, the tenants' space is lived and the space of the business owner, who is merely interested in higher rental income, is abstract space. The tension between tactics and strategies, inhabitance and habitat, lived and abstract space is aptly captured by the fact that the landlord attempted to justify the evictions by arguing that they were in line with the city's rejuvenation policies. The city of Johannesburg has an extensive fifty-five page Inner City Regeneration Charter. ${ }^{123}$ The Maphango case illustrates the tense relation between the rejuvenation of the city and the poor. The Johannesburg policy manages to capture this tension in stating that:

Our Inner City will not be a dormitory for the poor, nor an exclusive enclave of loft apartments, galleries and coffee shops. ${ }^{124}$

\section{$4 \quad$ Concluding remarks}

The majority decision in the Maphango case presents the possibility of an understanding of home that takes preference over business ventures, tactics over

119 Butler Henri Lefebvre 7.

120 Butler Henri Lefebvre 7.

121 Butler Henri Lefebvre 113. Butler quotes from Lefebvre Critique of Everyday Life III 50: "If the career of modernity as ideology is over, modernism as technological practice is more than ever with us ... From [the] great confusion ... emerges modernism: a clear field for the development of technology and the proclamation of the end of ideologies".

122 Lefebvre Production of Space 362.

123 Joburg date unknown http://www.joburg.org.za/index.php?option=com_content\&task= view\&id=1705\&Itemid $=49$.

124 The recent clamp down on informal traders contradicts this section of the Charter and other parts of the Charter that try to acknowledge that "City efforts have sometimes been seen as localised, fragmented and episodic and have been critiqued as not always sensitive enough to the circumstances of poorer residents and informal businesses". 
strategy, and inhabitance over habitat. The majority decision situates this distinction between business and home by explaining the historical context of the Rental Housing Act. ${ }^{125}$ In the minority judgment, considerations of public policy, fairness and the equitability of the rent to both the landlord and the tenant are more important. Judge Zondo emphasizes the landlord's economic justification for charging market-related rents. Abstract space, habitat and functionalism take preference. It captures an understanding of home in terms of which ownership and market-demands (strategies) turn apartments into business ventures (habitats) and thereby it diminishes the possibility of a home in the city centre of Johannesburg.

The tension between inhabitance and habitat in the Maphango case is illustrated not only in the opposing arguments of the parties but also through the majority and minority decisions of the Constitutional Court. The Constitutional Court did not grapple with this tension, but instead referred the matter to the Rental Housing Tribunal. On the one hand the Consitutional Court can be said to have avoided the problem, but in another sense, referring the matter back to the Housing Tribunal can be read as an "everyday" remedy. My contention is that the majority decision was in support of the tactics of the tenants and encouraged them and other tenants to follow an ordinary, everyday route in addressing rental disputes, namely the procedure available through the Rental Housing Tribunals.

To approach the notion of home from the vantage point of everyday practices as tactics and to acknowledge the political nature of inhabitance are to resist a romanticised, static and nostalgic conception of home. Instead, such an approach inscribes social relationships into the understanding of these spaces. Massey's understanding of spatial practices, place and space supports a dynamic and contested notion of "a place called home". ${ }^{126}$ She quotes Bell Hooks:

\footnotetext{
125 Maphango para 29. The housing shortages after World War I lead to the enactment of the Tenant's Protection Act 7 of 1920, which formed the centre of later rent control legislation. Judge Cameron quotes from Rosenow and Diemont Rents Act 1: the Tenant's Protection Act "provided that as long as a lessee paid the stipulated rent on due date, and performed all other conditions appurtenant to the lease, he or she could not be ejected unless the lessor required the premises for personal accommodation". The lessee was protected regardless of the amount of rent. As long as she paid the rent she was protected even if the rent was unreasonably low. 
Home is no longer just one place. It is locations. Home is that place which enables and promotes varied and ever-changing perspectives, a place where one discovers new ways of seeing reality, frontiers and difference. ${ }^{127}$

Home need not be a single and stable place or space but could be "home-places" that become equally complex products of "the ever-shifting geography of social relations present and past". ${ }^{128}$ The tactics of making do and the strategies of increasing rental income related to how the Lowliebenhof as a home-place was perceived and conceived of. The tenants filed a complaint with the Rental Housing Tribunal before the deadline prescribed by the Constitutional Court, ${ }^{129}$ but the case was not followed through. ${ }^{130}$ The living spaces in Lowliebenhof are now the homes of other tenants who can afford to practice everyday life there.

Hooks Yearning 171.

Hooks Yearning 172.

In May 2012 a complaint was filed with the Gauteng Rental Housing Tribunal. A copy of that complaint and subsequent activity on the case can be accessed at the website of the Social and Economic Rights Institute of South Africa (SERI 2014 http://www.seri-sa.org). The order in Maphango para 70 read: "Any of the parties may, if so advised, lodge a complaint in terms of section 13 of the Rental Housing Act 50 of 1999 with the Gauteng Rental Housing Tribunal on or before Wednesday 2 May 2012. If a complaint is lodged on or before that date, the parties are granted leave to apply to the Court within fifteen court days of the ruling by the Gauteng Rental Housing Tribunal, or other disposition of the matter, for further directions. If no complaint is lodged on or before that date, the appeal is dismissed with costs."

130 A telephone call to the Tribunal confirmed that the matter was never heard after the filing of the dispute. 


\section{BIBLIOGRAPHY}

\section{Literature}

Bourdieu Le Métier de sociologue

Bourdieu P Le Métier de sociologue $2^{\text {nd }}$ ed (Mouton La Haye 1973)

Brassey et al New Labour Law

Brassey MSM et al The New Labour Law (Juta Cape Town 1987)

Budlender "Towards a Right to Housing"

Budlender G "Towards a Right to Housing" in Van der Walt AJ (ed) Land Reform and the Future of Land-ownership in South Africa (Juta Johannesburg 1991) 45-52

Butler Henri Lefebvre

Butler C Henri Lefebvre: Spatial Politics, Everyday Life and the Right to the City (Routledge Oxon 2012)

De Certeau Practice of Everyday Life

De Certeau M The Practice of Everyday Life (translated from the original French by Rendall SF) (University of California Press Berkeley 1988)

De Certeau, Jameson and Lovitt 1980 Social Text

De Certeau M, Jameson F and Lovitt C "On the Oppositional Practices of Everyday Life" 1980 Social Text 3-43

De Certeau, Giard and Mayol Practice of Everyday Life Volume 2

De Certeau M, Giard L and Mayol P The Practice of Everyday Life Volume 2: Living and Cooking, (translated from the original French by Tomasik TJ) (University of Minnesota Press Minneapolis 1994)

De Ville Constitutional and Statutory Interpretation

De Ville JR Constitutional and Statutory Interpretation (Interdoc Consultants Cape Town 2000) 
Devenish Interpretation of Statutes

Devenish GE Interpretation of Statutes (Juta Cape Town 1992)

Du Plessis Interpretation of Statutes

Du Plessis LM The Interpretation of Statutes (Butterworths Durban 1986)

Foucault Surveiller et Punir

Foucault M Surveiller et Punir (Gallimard Paris 1975) (Discipline and Punish translated from the original French by Sheridan A) (Pantheon New York 1977)

Grogan Workplace Law

Grogan J Workplace Law $10^{\text {th }}$ ed (Juta Cape Town 2009)

Hooks Yearning

Hooks B Yearning: Race, Gender and Cultural Politics (Turnaround London 1991)

Klare 1998 SAJHR

Klare K "Legal Culture and Transformative Constitutionalism" 1998 SAJHR 146-188

Lefebvre Critique of Everyday Life

Lefebvre $\mathrm{H}$ Critique of Everyday Life (translated from the original French by Moore J) (Verso London 1991)

Lefebvre Critique of Everyday Life III

Lefebvre $\mathrm{H}$ Critique of Everyday Life III: From Modernity to Modernism (Towards a Metaphilosphy of Daily Life) (translated from the original French by Moore J) (Verso London 2005)

Lefebvre Production of Space

Lefebvre $\mathrm{H}$ The Production of Space (translated from the original French by Nicholson-Smith D) (Blackwell Cambridge 1991) 
Maass 2012 SAPL

Maass S "Conceptualising an Unfair Practice Regime in Landlord-tenant Law" 2012 SAPL 652-670

Maass 2012 PER

Maass S "Rent Control: A Comparative Analysis" 2012 PER 15(4) 41-100

Massey Space, Place and Gender

Massey D Space, Place and Gender (Polity Press Cambridge 1994)

Michelman 2012 Harvard Public Law Working Paper

Michelman F "Expropriation, Eviction, and the Dignity of the Common Law" 2012 Harvard Public Law Working Paper No 12-37

Philippopoulos-Mihalopoulos 2010 Int'/ JLC

Philippopoulos-Mihalopoulos A "Spatial Justice: Law and the Geography of Withdrawal" 2010 Int'/ JLC6(3) 201-216

Roberts Philosophizing the Everyday

Roberts J Philosophizing the Everyday (Pluto Press London 2006)

Rosenow and Diemont Rents Act

Rosenow REG and Diemont MA The Rents Act in South Africa $2^{\text {nd }}$ ed (Juta Cape Town 1950)

Stoop 2013 IJPL

Stoop PN "The South African Law of Lease and Socioeconomic Rights" 2013 IJPL 329-340

Tau The Citizen

Tau S "Crackdown on Street Traders" The Citizen (23 October 2013) 9

Van der Walt Property and Constitution

Van der Walt AJ Property and Constitution (PULP Pretoria 2012) 
Van der Walt Land Reform

Van der Walt AJ (ed) Land Reform and the Future of Land-ownership in South Africa (Juta Johannesburg 1991)

Van Marle and De Villiers 2013 AFL

Van Marle $\mathrm{K}$ and De Villiers I "Law and Resistance in the City of Pretoria: Space, History and the Everyday" 2013 AFL 129-145

Van Niekerk etal Work@Law

Van Niekerk A et al Work@Law (LexisNexis Durban 2008)

Von Clasewitz De la Guerre

Von Clasewitz K De la Guerre (Ed de Minuit Paris 1955)

\section{Case law}

City of Johannesburg Metropolitan Municipality v Blue Moonlight Properties 20114 SA 337 (SCA)

City of Johannesburg Metropolitan Municipality v Blue Moonlight Properties 39 (Pty) Ltd 20122 BCLR 150 (CC)

Cooper v Trustee in Insolvent Estate of Pretorius 19673 SA 602 (O)

Fundstrust (Pty) Ltd (in liquidation) v Van Deventer 19971 SA 710 (A)

Gundwana v Steko Development 20113 SA 608 (CC)

Jaftha v Schoeman; Van Rooyen v Stolz 20052 SA 140 (CC)

Maphango v Aengus Lifestyle Properties 20115 SA 19 (SCA)

Maphango v Aengus Lifestyle Properties (Pty) Ltd 20125 BCLR 449 (CC)

Marievale Consolidated Mines v President of the Industrial Court 19862 SA 485 (T)

Media Workers Association of South Africa v Press Corporation of South Africa Ltd 19924 SA 791 (A)

National Entitled Workers Union v Commission for Conciliation, Mediation and Arbitration 20077 BLLR 623 (LAC)

National Union of Metalworkers of South Africa v Macsteel (Pty) Ltd 19923 SA 809 
National Union of Mineworkers v East Rand Gold and Uranium Co Ltd 19921 SA 700 (A)

Nawa v Department of Trade and Industry 19987 BLLR 701 (LC)

Occupiers of Portion R25 of the Farm Mooiplaats 355 JR v Golden Thread Ltd 20124 BCLR 372 (CC)

Occupiers of Skurweplaas 353 JR v PPC Aggregate Quarries (Pty) Ltd 20124 BCLR 382 (CC)

Occupiers, Shulana Court, 11 Hendon Road, Yeoville, Johannesburg v Steele 20104 All SA 54 (SCA)

Reddy v KwaZulu-Natal Department of Education and Culture 200324 ILJ 1358 (LAC)

$S v$ Marais 19823 SA $988(\mathrm{~A})$

SABC Ltd v CCMA 20103 BLLR 251 (LAC)

SAFRAWU obo Members / Rainbow Farms 200211 BALR 1184 (CCMA)

Schubart Park Residents Association v City of Tshwane Metropolitan Municipality 20131 BCLR 68 (CC)

\section{Legislation}

Constitution of the Republic of South Africa, 1996

Employment Equity Act 55 of 1998

Labour Relations Act 66 of 1995

Rental Housing Act 50 of 1999

Rental Housing Amendment Act 43 of 2007

Sectional Titles Act 95 of 1986

Tenant's Protection Act 7 of 1920

\section{Government publications}

PN 4004 in PG 124 of 4 July 2001

PN 4216 in PG 127 of 18 July 2001 


\section{Internet sources}

Google Maps 2010 https://maps.google.co.za/maps?ie=UTF-8\&q=Lowliebenhof\&fb= 1\&gl=za\&hq=lowliebenhof\&hnear=0x1e95619cbec65033:0xf66262b07a847b 4c,Pretoria\&cid=0,0,666638301094739748\&ei=8HWDUp-mFdCihgewj4Gw Dw\&ved $=0 \mathrm{CJgBEP}$ SMAs Google Maps 2010 Lowliebenhof https://maps.google.co.za/maps?ie=UTF$8 \& q=$ Lowliebenhof\&fb=1\&gl=za\&hq=lowliebenhof\&hnear=0x1e95619cbec65 033:0xf66262b07a847b4c,Pretoria\&cid=0,0,666638301094739748\&ei $=8 \mathrm{HWD}$ Up-mFdCihgewj4GwDw\&ved=0CJgBEPwSMAs accessed 20 October 2013

Joburg date unknown http://www.joburg.org.za/index.php?option=com_ content\&task=view\&id $=1705 \&$ Itemid $=49$

Joburg date unknown $A n$ Introduction to the Inner City Charter http://www.joburg.org.za/index.php?option=com_content\&task=view\&id=17 05\&Itemid $=49$ accessed 20 October 2013

SERI 2013 http://www.seri-sa.org/index.php/38-latest-news/202-seri-condemns-thecrack-down-on-informal-traders-in-inner-city-johannesburg-23-october-2013 Social and Economic Rights Institute of South Africa 2013 SERI Condemns the Crack-down on Informal Traders in Inner City Johannesburg http://www.serisa.org/index.php/38-latest-news/202-seri-condemns-the-crack-down-oninformal-traders-in-inner-city-johannesburg-23-october-2013 accessed 24 October 2013

SERI 2014 http://www.seri-sa.org

Social and Economic Rights Institute of South Africa 2014 About Us http://www.seri-sa.org accessed 24 October 2013

\section{LIST OF ABBREVIATIONS}

AFLJ

CCMA

IJPL
Australian Feminist Law Journal

Commission for Conciliation, Mediation and Arbitration

International Journal of Private Law 
Int'I JLC

SAJHR

SAPL

SERI

PER
International Journal of Law in Context South African Journal on Human Rights

South African Public Law

Social and Economic Rights Institute of South Africa

Potchefstroom Electronic Law Journal 